\title{
A PEACEBUILDING FROM THE BOTTOM: DAILY LIFE AND LOCAL GOVERNANCE IN RURAL AFGHANISTAN
}

\author{
Yutaka Hayashi*
}

\section{Introduction}

The images of Afghanistan are quite often occupied with the long history of conflicts since late 1970s. Even some knew the assassination of Ahmad Shah Massoud on the eve of 911 attacks on the US soil in 2001. The year of 2001 was a historic turning point for the country to re-start state building from the ashes of two decades of war. In other words, 2001 can be seen as a new beginning of peacebuilding in Afghanistan.

This article will examine a possible peacebuilding in Afghanistan from the perspective of rural life after 2001. It is often argued that peacebuilding means to establish state institutions and rule of laws and to introduce a democratic system. This paper, however, aims to highlight the rural daily life and local governance system in order to lead a stable and effective peacebuilding in Afghanistan. For that purpose, based on the interviews conducted between 2003 and $2013^{1}$ it is, therefore, emphasised that the importance of peacebuilding in rural area, not the top-down peacebuilding, is critical to materialise peace in the country.

This article will investigate the life in rural Afghanistan and based on that, highlights the descent and humble needs of villagers, farmers and ex-combatants for life that directly indicate a way to establish peace from rural area. It would also imply the gap between the reconstructions of state system and the needs of the people in rural area. This article, therefore, (1) touches upon brief background of the targeted rural districts, and (2) examines the needs of the people in the rural area and finally (3) highlights the community structure and local governance in rural Afghanistan.

\section{Turmoil in Afghanistan since 1970s}

Afghanistan, a conflict affected South Asian Islamic Republic, witnessed longstanding violent conflicts that started in 1970s. Since 1919, Afghanistan became a sovereign country as a kingdom. Once the kingdom of Afghanistan enjoyed calm and peaceful time, but with slow economic development. King Zahir Shah introduced a democratic political system (1963-1973), the first constitution (1964) and the first general election (1965). The turmoil of the country began with the coup d'état in 1973 and the result was the establishment 
of the Republic of Afghanistan. The first president of Afghanistan Daud Khan, however, was not able to maintain his power. On the 28 of April 1978, the so-called Saur Revolution, the pro-communist People's Democratic Party of Afghanistan (PDPA) took over the political power from Daud Khan and assassinated him in the presidential palace on the day. Accordingly, the name of the country changed from the Republic of Afghanistan to the Democratic Republic of Afghanistan. The new government brought radical changes to rural life by land reform and so on. Consequently, it caused rural aversion and then armed uprising. The political and security situation created a cause for Russian invasion in December 1979, which was marked as the beginning of the Afghan conflict. Since then, the country was in conflict, at the same time, it is possible to say that this is the beginning of the process that undermined and decomposed the state system of Afghanistan. Because of the prolonged conflict, the decomposing process continued until 2001.

After the 911 attacks and subsequent intervention by US/NATO and allied forces, the situation in Afghanistan changed its nature. Since 1992 up to 2001, the conflict in Afghanistan was a "forgotten war" waged by local and domestic players, but after the collapse of the Taliban regime, massive international assistance flooded into the newly established Islamic Republic of Afghanistan for reconstruction. After 2001, although there are insurgencies in Afghanistan, the newly established Islamic Republic of Afghanistan ${ }^{2}$ became an internationally recognised sovereign state and the sole recipient of international assistance inside the border. The national and international efforts are made to restore the state system and the life of the people after the decades of conflict. While the effort to reconstruct state system continues, the vast majority of the nation (72 per cent) lives in rural areas and 5 per cent of people maintain nomadic life (CSO 2012). In that sense, it would be crucial to re-establish the rural life for the majority of the nation and it automatically means that peacebuilding in the rural areas is directly related to the peacebuilding of the country.

\section{Previous Studies}

The international effort to reconstruct Afghanistan also created a surge of research interest in the country, but since 1960s and 70s, there were several studies on rural Afghanistan. Dupree studied pre-war rural Afghanistan during 1970s and his writings provide basis of rural research ${ }^{3}$. After the breakout of conflict in Afghanistan, Kakar suggested that the rise of religious leaders (Mullahs) ${ }^{4}$ in rural areas as providers of channels to obtain weapons and resources, and the emergence of commanders as users of physical power, while Mullahs did not have much power during pre-war Afghanistan ${ }^{6}$. At the same time, the rise of warlords and commanders from the sons of rural traditional leaders was also depicted after $1979^{7}$. 
After 2001, witnessed the increase of research on rural Afghanistan. Wily investigates rural society focusing on land tenure system and points out that due to the conflicts land tenure became one of the major issues in rural Afghanistan ${ }^{8}$. Wily also suggests that resolving land right issues in agricultural areas can contribute to the lasting peace and stability9.

It is highlighted that the influence and control of central government in rural areas is limited and the rule of laws in those areas is not fully implemented ${ }^{10}$. Deschamps claimed that the inability of the justice system to handle the cases concerning the land tenure/right and judgment outside formal judicial system would undermine the legal system ${ }^{11}$. In fact, it is reported that villagers are not relying on the government but using Taliban courts to solve their cases concerning land, inheritance and family disputes ${ }^{12}$.

From the perspective of political history, it is analysed that Afghanistan has a strong tribal society and delayed centralisation of power ${ }^{13}$. Grace also indicates that, as a reality in rural Afghanistan, villages operate apart from the state system and rule of laws ${ }^{14}$. Those arguments mentioning state-society relations would lead us to the insight of Migdal ${ }^{15}$. Using the title of Migdal's book, Saikal called the inability or malfunctioning of the state and functioning community in Afghanistan as weak state and strong society ${ }^{16}$. In that sense, it would be possible to say that Saikal developed the previous state-society analysis in the context of Afghanistan.

While there are several areas of research on rural Afghanistan, the majority of peacebuilding studies focus on reconstruction of the state system in order to recover from the failed state situation in the post conflict period ${ }^{17}$. On the one hand, the emphasis is given to state building ${ }^{18}$, others highlight the importance of the rule of laws ${ }^{19}$.

In this regard, it should be noted that those discourses are 'state-centric' and disregard the detailed research at village level. It is, therefore, meaningful to review the peacebuilding process based on the reality of micro-level, namely, village and community level. This is why this article examines a case study of rural Afghanistan to highlight possible approaches for peacebuilding in rural areas.

\section{Historical Background of the Targeted Districts; Kalakan and Mir Bacha Kot}

The case study is based on the interviews in the northern districts of Kabul Province where different military powers waged decades of violent conflicts. The targeted districts, Kalakan and Mir Backa Kot, were one of the fiercest battlegrounds in the region (Map 1 and 2). Map 1 showed that the area experienced fierce battle because of the main road connecting Afghanistan with former USSR where Afghan Mujahedeen conducted attacks against Russian troops alongside 
the main road. As a result, landmines were planted and UXOs (Unexploded Explosive Ordnances) were left in the region (Map 2).

Map 1: Targeted Districts: Kalakan and Mir Bacha Kot, and two Main Roads

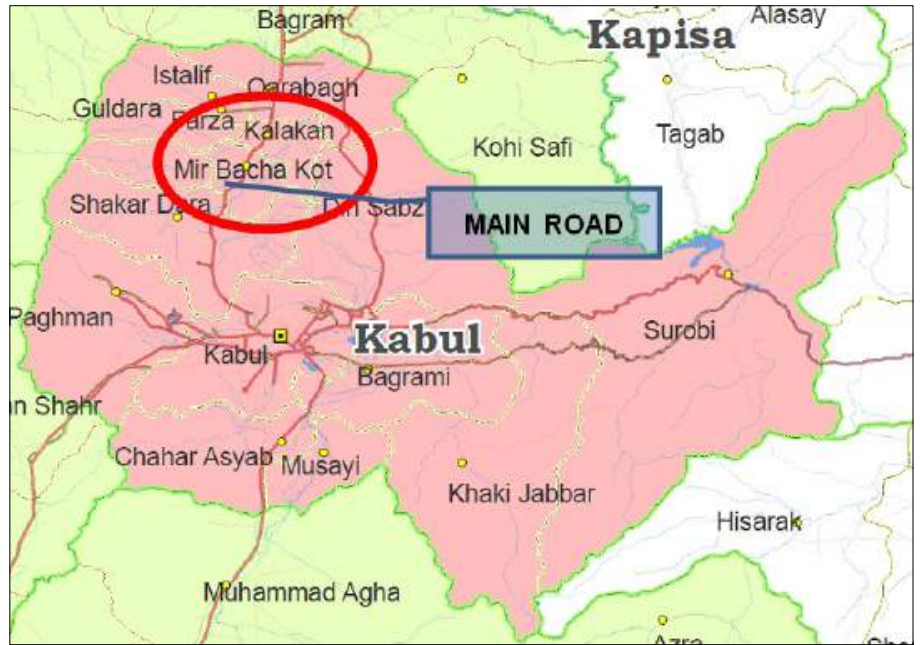

Source: AIMS modified by the Author

Map 2: Targeted Districts: Kalakan and Mir Bacha Kot and Landmines/UXOs Impacts

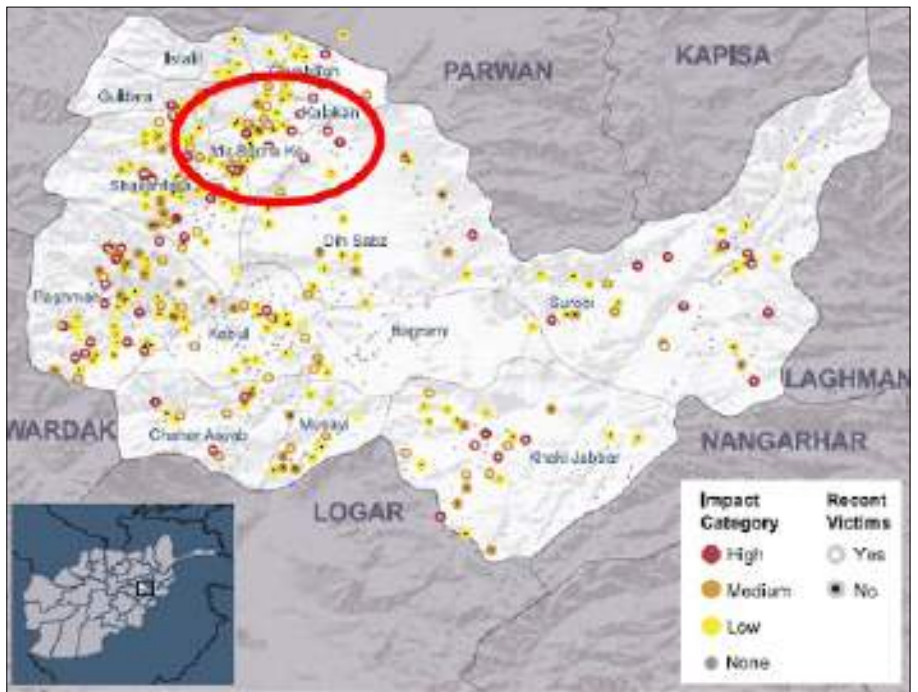

Source: Landmine Impact Survey 
Large number of the farmers living there once took their weapon to fight. After the emergence of Taliban in the region, villagers in the northern parts of Kabul, including both Kalakan and Mir Bacha Kot, mainly the minority Tajik, were forced to move by Taliban ${ }^{20}$.

The Shomali plain, northern part of Kabul Province including Parwan Province, was once a large source of wheat and called as "Breadbasket of Kabul". In addition, the Shomali plain was well-known grape producing area and until 1970 s, Afghanistan account for around $60 \%$ of dried fruits in the global market ${ }^{21}$.

Most of villages in Kalakan and Mir Bacha Kot districts took the side of Rabani and Massoud, and during Taliban era, majority of their grape trees and $\mathrm{Karez}^{22}$ (underground water tunnel) were destroyed by Taliban. Mosques and houses in the area were also set on fire and burned down.

The impact of such harsh conflicts resulted in the migration of the villagers in the two districts. Figure 1 showed the places where villagers of the two districts spent their life during the conflicts. Based on the interviews conducted by the author, $45 \%$ of villagers escaped to other countries (Pakistan 39\%, Iran 6\%). Those who stayed inside the country (53\%) went to other provinces. Out of the $53 \%, 37 \%$ went to the Northern Alliance controlled area or Tajik-majority area (Charikar (Parwan Province) 28\%, Panj Shir Province 9\%, and Kabul Province 10\%) ${ }^{23}$.

Figure 1: Impact of Conflicts:

Places lived outside Kalakan and Mir Bacha Kot during conflicts

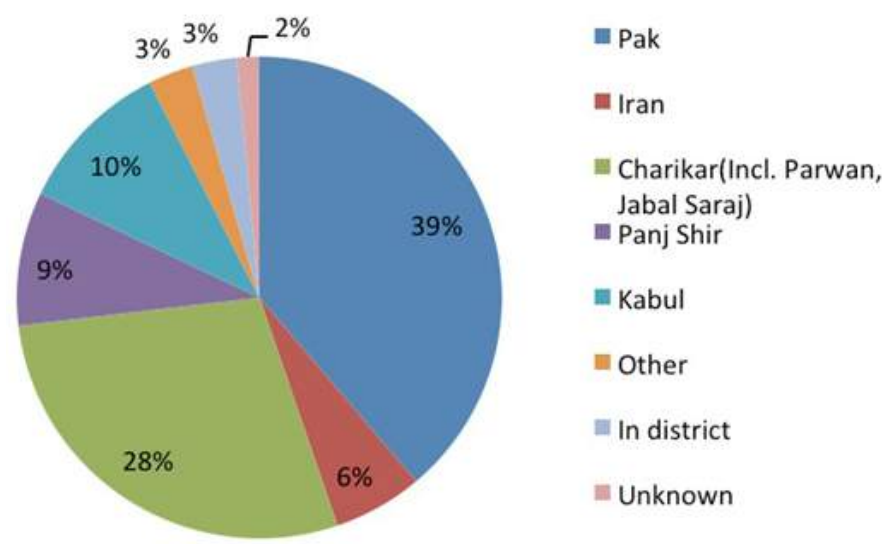

Source: Interviews by the Author (December 2004)

Based on the interviews, the villagers responded that almost 90 per cent of residents returned to their villages after the year of 2001. It was, however, not easy for them to re-start their life in the villages because of the destruction of 
houses, Karez, grape gardens and farm lands. In addition, the villagers in the age of 30s and 40s, most of them lost the opportunity for education during the conflicts. Majority of the age group of 30s and 40s are illiterate and among the age group, large number of males joined the battle and now returned to the community without productive skills except farming. Thus, job opportunities for those ex-combatants are quite limited. For instance, those ex-combatants only can work as day labourers.

This historical background of the two districts would make sense to focus on the area to consider a peacebuilding from the perspective of rural area.

\section{Life of Villagers and Needs of People in Rural Area}

During the war time, a large number of male members of Kalakan and Mir Bacha Kot districts took their weapon and joined the conflicts. At the time of joining the conflicts, a consideration was paid on each family to have male member in each family to take care of the household and farmland ${ }^{24}$. At least one male member was left for each family and other males were attending the conflicts in the mountains or battlefields. After 2001, those ex-combatants returned to their village and re-started their life as farmers or day labourers in and around Kabul.

Most of the villagers own farmland or grape garden and produce grape, wheat, and vegetables. Figure 2 indicate the agricultural calendar in the northern part of Kabul Province.

Figure 2: Agricultural Calendar in Kalakan and Mir Bacha Kot Districts

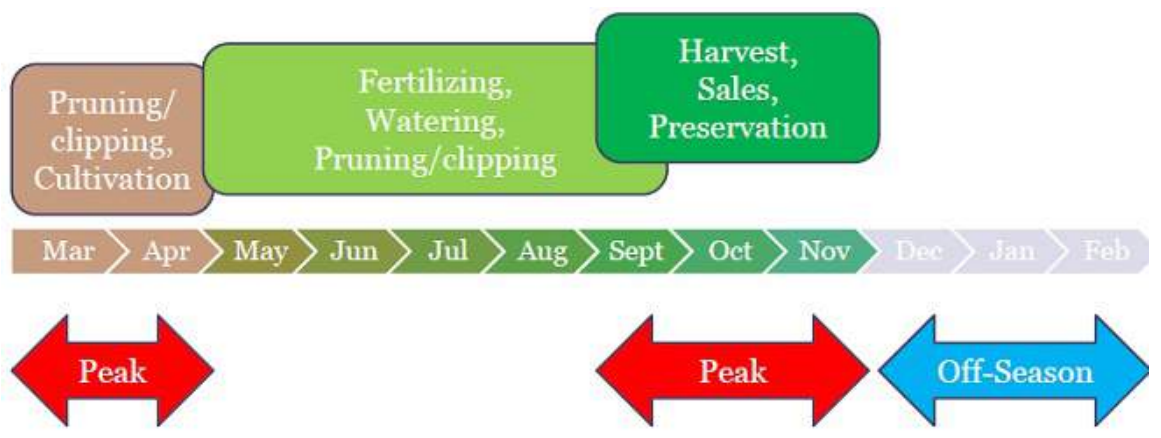

Source: Interviews by the Author

The off-season in winter period, namely, December, January and February, farmers call it as "short blanket (in the 12 months, they can work only 9 months)". If the harvest cannot provide enough income for the household, then, farmers usually go to day labour in Kabul or nearest large cities in next province (Parwan Province). 
Interviews conducted by the author suggest that (1) Economic situation (cash/ income, owing land or not), (2) Jobless (unemployment especially during winter), (3) Water (available water for farmland) are the biggest difficulties in the rural area (Figure 3). In addition, (4) Availability of electricity and farming materials such as agrichemicals and equipment is also mentioned ${ }^{25}$.

Figure 3: Biggest Problem in the Life of Village

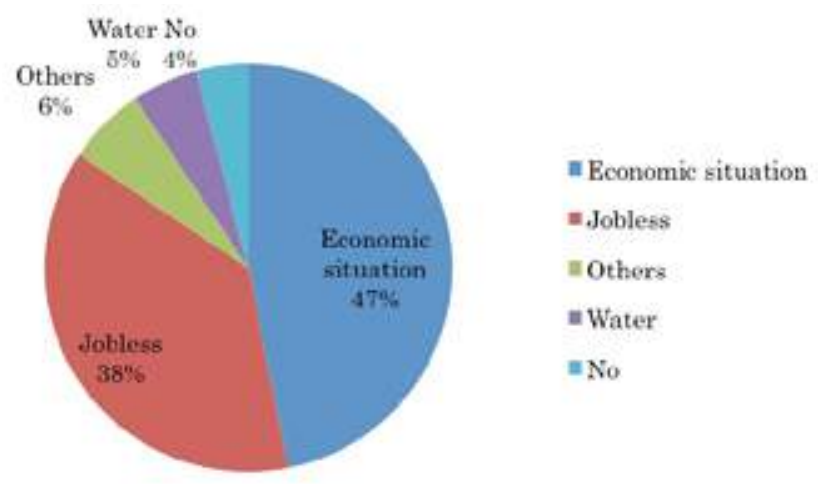

Source: Interviews by the Author

As for (1) Economic situation, farming in Kalakan and Mir Bacha Kot district allows villagers only 9 months work and for the other 3 months, they have to wait the arrival of spring without doing anything. This is a huge economic loss for the villagers.

On (2) Jobless, the answer seems very understandable and reasonable. Considering the job availability in the rural area, any job (apart from farming of their own land) can be a supplemental source of cash and income. Many respondents are taking up farm labour or any type of labour in and around the district. Although the availability and prospect of labour work would be unstable, people still can get some extra cash for their household ${ }^{26}$.

Regarding (3) Water, in Afghanistan, Iran and other central Asian countries, water means farmland. If there is no water, then, there is no farmland, which means that the land can be farmland or dessert. It solely depends on the water availability. It is, therefore, obvious that the water availability is crucially important for farmers in the region.

Finally, (4) Electricity, before 2001, grid line of electricity was totally not available, but after 2001, gradual expansion of grid line can be seen as a visible peace dividend. Even the rural communities, people hope to have the electricity for their life and for their children. The power supply can be used for lights, TV, 
mobile and so on. As for the farming materials, agrichemicals (fertiliser etc.) and equipment are the additional means to improve their harvest.

Those four above indicate that the wishes of rural villages are focusing on their life, not something related to government or security. In this connection, it should be noted that the first priority for the villagers are not security, governance or corruption, but their normal life and its improvement. The results of interviews highlight a gap between the needs of local people and the focus of international assistance. Quite often, international communities, donor agencies or UN agencies try to re-establish a state system in the post-conflict situation, but as a result above showed that people on the ground do not consider their government or the way of governance. Huge amount of foreign assistance is pouring into the governance, security and reconstruction of state system as peacebuilding efforts, but the focus does not match with the needs of the villagers.

It seems that this discrepancy is creating frustration among the majority of nation, namely, farmers and rural villagers. It would understandable that farmers and villagers think they do not benefit from the massive inflow of money donated by foreign countries. This is because farmers and rural residents are still struggling with their daily life while the capital is developing and expanding with the foreign assistance.

In that sense, the discrepancy indicates a gap between international peacebuilding efforts and local efforts for life. In other words, we need to rethink the approach for peacebuilding in the context of local perspective. It would be essential for the foreign assistance or official development assistance to reflect and respond to the needs of the majority of the nation.

\section{Local Community Structure and Its Relation with Governments}

The villagers organise community structure to govern themselves. Afghanistan has 34 provinces and 364 districts. Under the central government, there are Provincial governments and District governments. The smallest official administration unit is district, and one district consists of several villages and communities. Each village and community has its own governing body. In the case of northern districts of Kabul Province, the governing body is called as 'Shura ${ }^{27}$. Shura is not an official administrative institution, but an indigenous community structure.

There are two levels of Shura, that is, Village level Syura (Shura-e Qariya: Council of Village) and District level Shura (Shura-e Mardomi Ursowali: Council of the people of District). Usually a village is formed in a walking distance from Mosque, and a village has a Shura-e Qaliya (Figure 4). Outside of formal and official administrative organisations, villagers operate their area through Shura-e Qariya. People select the members of Shura (Kalan/Bozorgan: Elders) by 
discussion and the qualifications for a member are not based on financial status or family lines but on the character, wisdom, and literacy. Then, those members of Shura select a Malik (Representative). Malik does not have any given years of term, but if villagers file complains to Shura, then, Shura will have another discussion to evaluate the Malik. The same procedures can be applied to the members of Shura. Shura is held at Mosque having the attendance of Mullah and, contrary to author's expectation, Mullah functions only as an religious advisor for Shura.

Figure 4: Village level governing body: Shura-e Qariya

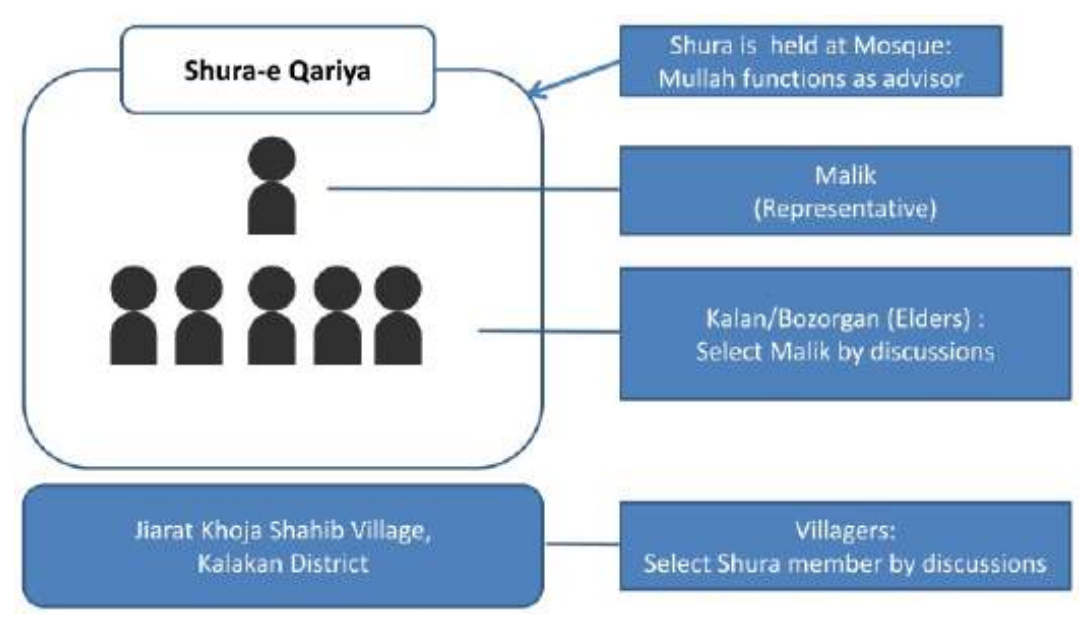

Source: Interviews by the Author

Shura handles decision makings such as supporting very poor villagers/ widows, issues of water allocation and farmland demarcation, request of infrastructures for the village (bridge, road, school and hospital, electricity) to national and provincial governments and so on.

Above the Shura-e Qariya, there is a Shura-e Mardomi Ursowali, which comprises Maliks representing each village (Figure 5). Maliks select Raise (Leader of District). Although the Constitution of Afghanistan prescribes the establishment of District Council, currently there is no district council in reality. Instead, Shura-e Mardomi Ursowali substitutes the function.

In addition, the District Governor is dispatched from the central government, which means that the Governor does not know the detailed matters in his/her assigned district. Therefore, the Governor usually follows and approves the suggestions and decisions made by Shura-e Mardomi Ursowali. In that sense, the Governor is depending on the knowledge and leadership of the Raise and Shura (Figure 6). 
Figure 5: District level governing body: Shura-e Mardomi Ursowali

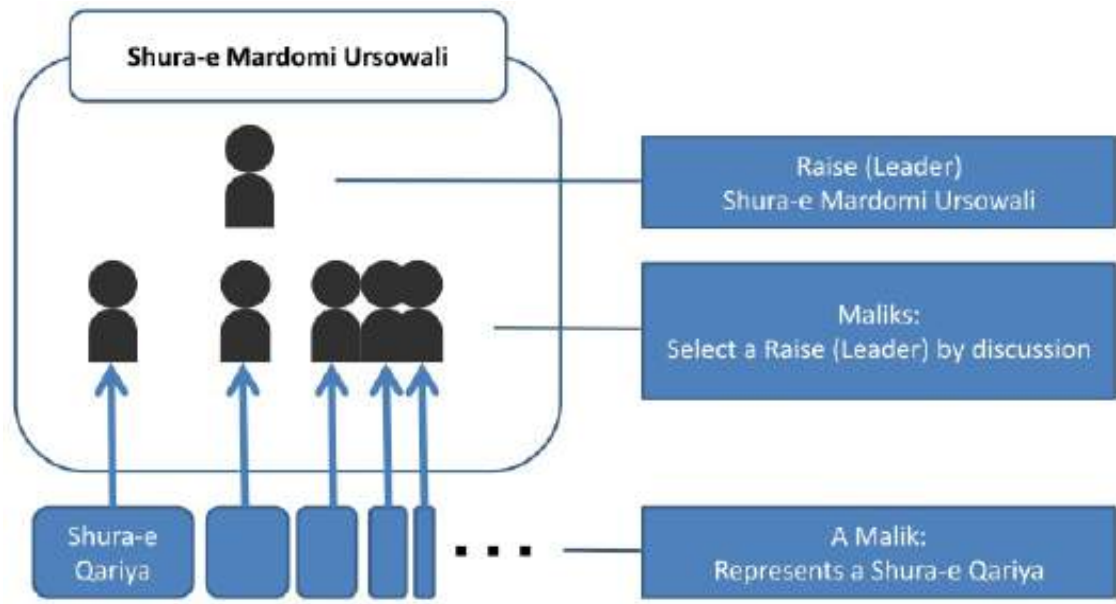

Source: Interviews by the Author

Figure 6: Shura-e Mardomi Ursowali and Government

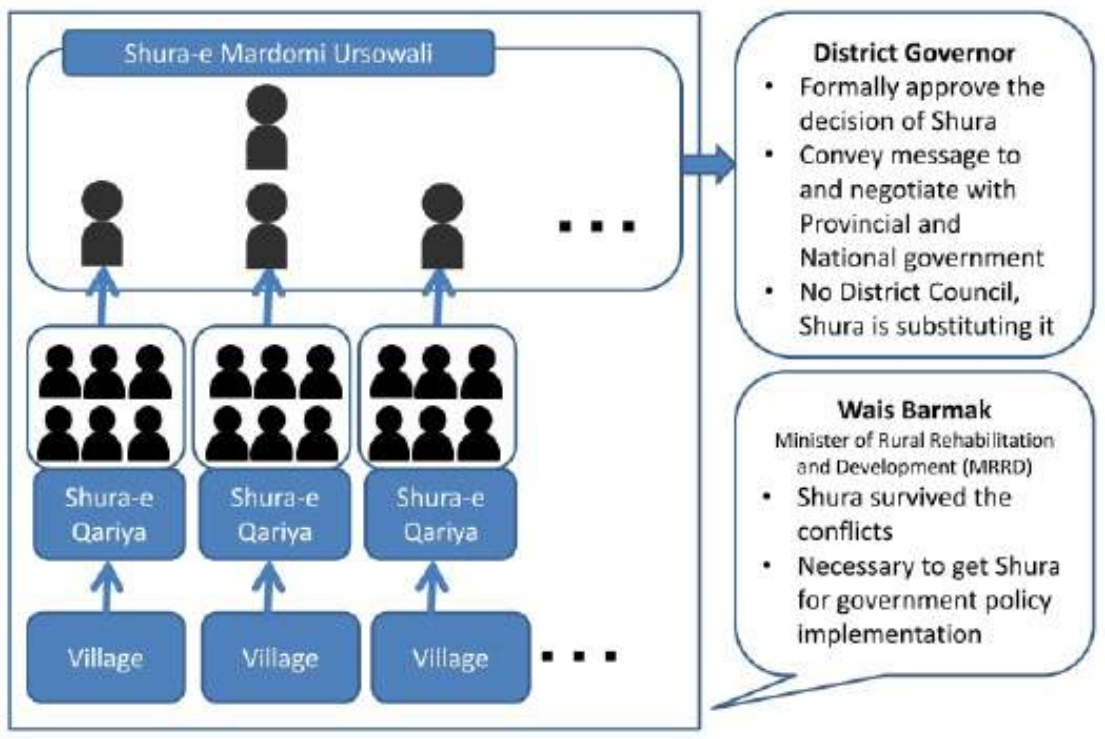

Source: Interviews by the Author

As described above, Shura has enough knowledge on the area and plays important role in the rural Afghanistan. The Minister of Rural Rehabilitation 
and Development (MRRD) acknowledged rural farmers and ex-combatants as 'backbone of Afghanistan' and mentioned that 'it is important to include Shura which functioned during and after the conflict in the process of implementing government policy in rural area ${ }^{28}$.

What is indicated here is the importance of Shura for the peacebuilding and reconstruction in rural areas. It is widely reported the high prevalence of the corruption of Afghanistan (Transparency International, 2012), but Shura is functioning better than the central government in rural area. Shura both in village as well as in district level can gather the voices of the villagers and reflect their wishes into the policy in the district. Shura is also supported by the residents because of the fairness and transparent process of selection for its members.

Although Shura cannot directly solve economic difficulties of the villagers, it can facilitate better environment for their village and district through the interaction with the District Governor. In this regard, it would be possible to say that Shura can be seen as a funnel to convey the wishes of the village/district to the state system. On top of that, it is observed that the Shura members have the mobile phone numbers of the Member of Parliament selected from the region ${ }^{29}$. If Shura wants to get something, they directly call to the politicians and solicit their support.

Regarding the power and influence in the village and community, Figure 7 shows the answers of the respondents. It is no doubt that the issue of land in the rural area would be critical. In the case when land disputes happen, Figure 7 indicates that villagers go to Malik (63 per cent), followed by elders in the village (20 per cent). Only 4 per cent of villagers ask District Governor to solve land disputes. This would mean that residents in rural area see Malik and elders have the power and authority as well as enough knowledge on the land and related matters. It is, however, interesting that people do not go to Shura (4 per cent) to solve the land issues. This might be interpreted that Shura as a council of multiple members would not be so suitable to make a quick decision on urgent matters such as land.

Based on Figure 7, it is quite reasonable to say Malik and elders as biggest decision makers in the village. Figure 8 suggests that Malik ( 64 per cent) and elders (20 per cent) are the biggest decision makers on the matters in the community. Both Malik and elders know the past and present on the village matters, therefore, rural residents can rely on and trust their decisions. In addition, when community member asks Malik, elders and Shura to handle contested matters, there will be no need to pay any fee or money for the judgment or arbitration. On village matters, it seems that people would not turn to District Governor (4 per cent), as this paper has already mentioned, District Governor is an outsider. 
Figure 7: Who has the Power and Authority to Solve Land Dispute?

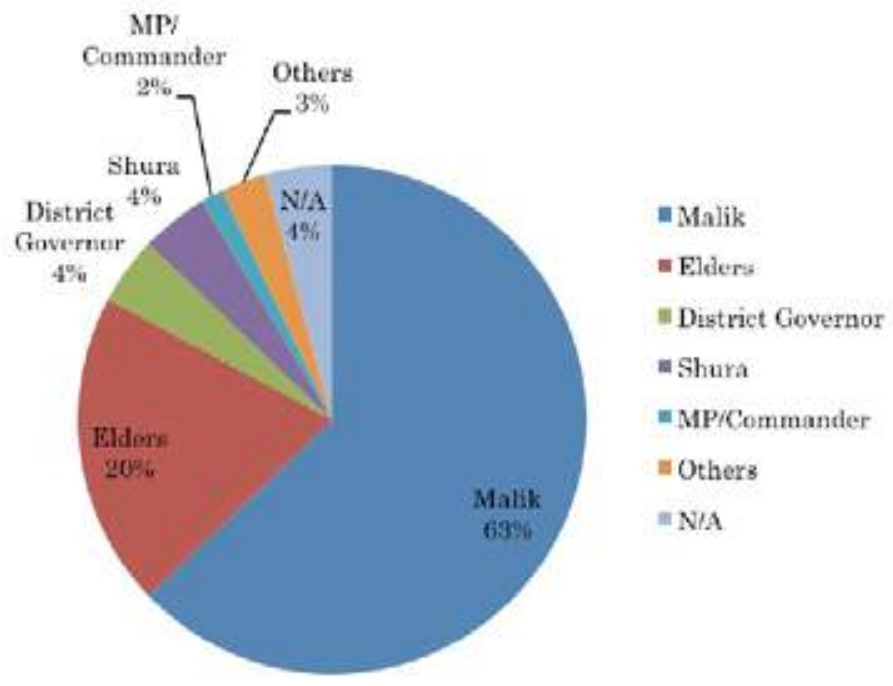

Source: Interviews by the Author

Figure 8: Biggest Decision Maker on the Village Matters

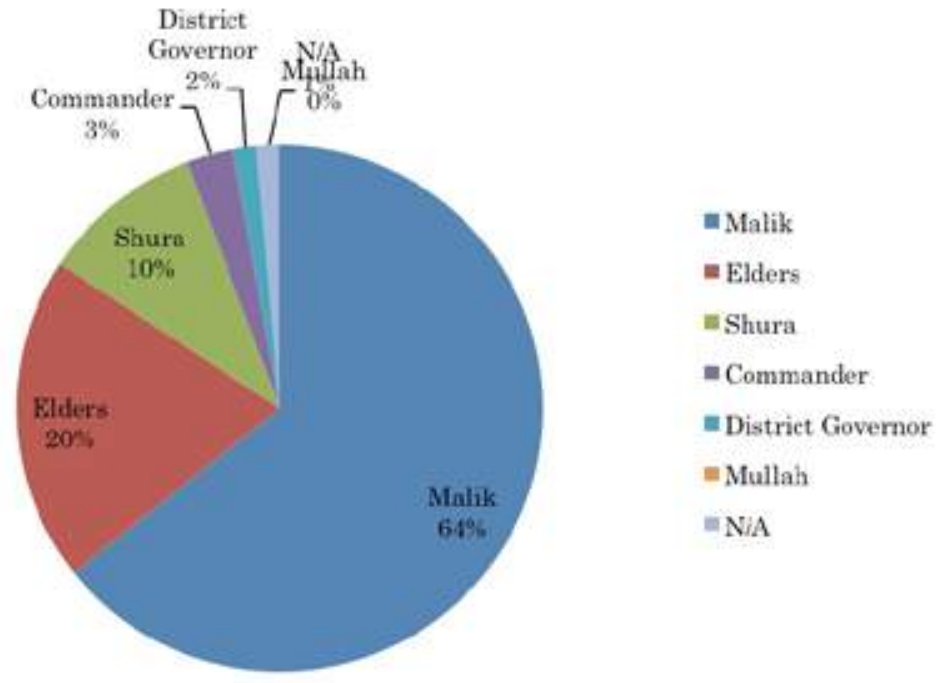

Source: Interviews by the Author 
It does not, however, mean that District Government has power or authority in the community. Figure 9 shows the perception of rural residents on District Government. Apparently, people recognise the power and authority of District Government (42 per cnet). Malik and Shura are also seen to have the power and authority in their community, but Figure 9 indicates that people are wisely choosing the institutions to express their demands and claims, to ask for arbitration, and to handle the matters at hand.

Figure 9: Who Has More Power and Authority?

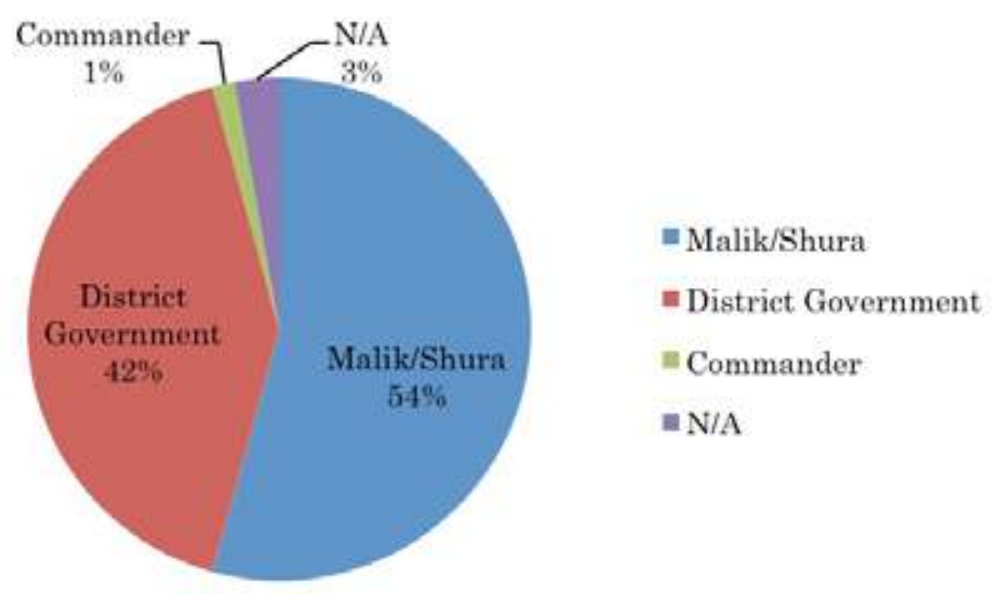

Source: Interviews by the Author

In the rural communities, people are using traditional system, that is, Shura and its head, Malik, as an institution to manage daily and ordinary matters and to convey their request to the formal state system. At the same time, although District Governor is an outsider, local residents acknowledge the power and authority of the District Government as an official and formal governmental organ in the rural area. In addition, former commander of the area is now a Member of Parliament, and people also use the former commander as an other informal way to transmit their wishes to the state system. Those formal and informal, traditional and governmental institutions create multiple layers of structure in the rural areas and local residents are selective in the use of those institutions according to the nature of the matter. In the rural areas, the local governance is built upon complex layers of formal and informal institutions and working in a very effective way to tackle daily and local issues. 


\section{Conclusion}

The peacebuilding in rural Afghanistan was a reconstruction of life for the villagers. Daily decision and issues are handled by Shura. After seeing decades of war, they are now trying to make peaceful life through Shura and it is mainly done outside the central, provincial and district governments. The communities are using government organisations through Shura.

The interview results showed that what people wants is to make a better living, and they suggested that there is a gap between those needs at local level and international peacebuilding efforts at national level.

Peacebuilding at national level can be translated into state system reconstruction and re-establishment of state governance but peacebuilding at local level can be brokendown into the reconstruction of daily life. In the ordinary life in rural areas, central issues are related to their life, such as economic situation, water and electricity, not the state system.

International assistance tends to focus on the reconstruction of state system as an approach for peacebuilding for the post conflict countries or collapsed states, but what is suggested here is that we need to change our mindset for the notion of peacebuilding. The abstract word, peacebuilding, should be analysed and translated based on the real aspects of farmers and villagers in Afghanistan.

Lamb stated that there is a gap of perception between the people of Afghanistan and outsiders. While international observers compare today's Afghan governance with what it could be, for the nation, government with corruption or malfunction is better than that with a mass murderer ${ }^{30}$. This remark and the case study in rural Afghanistan urge us to look into the perceptions of people on the ground in detail, not to rely on our textbook knowledge of peacebuilding or post conflict reconstruction.

Following to the findings in this article, it would be possible to suggest some policy recommendations:

- In order to make visible, tangible, and positive impact in rural areas, the developmental and peacebuilding efforts by the international community and by the government should focus on the improvement of the economic situation, water and electricity in rural regions.

- Both the international and governmental actors needs to change the mindsets of peacebuilding, not based on the internationally and academically common understanding and practices of peacebuilding, but based on the viewpoints of villagers and farmers to respond to the needs on the ground.

- For the international community and the government, the term "governance" should be understood not totally relying on the textbook knowledge, but 
through the perception of rural residents. For them, the government with corruption and infectiveness might be better than that with killers. Priority should be given to the perceptions and needs of the people, not to the globally common knowledge and practices on good governance.

- The government should increase the effort to incorporate the Shura/Jirga system into the formal governmental decision making procedure. Shura and Jirga can provide detailed information, critical needs, and priority for development projects.

- Villagers and rural residents can increase the transactions with the governmental, provincial and district institutions through their channels in order to meet their needs, for instance, the use of former commanders and current Members of Parliament from their region. Those figures have much influence over the government and know the reality and needs of rural life.

\section{References}

Afghanistan Information Management Services, Regional Maps Zone 1.

Central Statistics Organization (CSO), 2012, Statistical Yearbook 2011-2012, Islamic Republic of Afghanistan.

Deschamps, Colin, and Roe, Alan, 2009, Land conflict in Afghanistan: Building capacity to address vulnerability, Kabul: Afghanistan Research and Evaluation Unit.

Dupree, Louis, 1973, Afghanistan, Princeton University Press.

FAO, 2004, Afghanistan - Survey of the horticulture sector 2003, Rome: Food and Agriculture Organization, United Nations.

Fukuyama, Francis, 2006, Nation-building: Beyond Afghanistan and Iraq, Baltimore: Johns Hopkins University Press.

Fukuyama, Francis, 2004, State-building: Governance and world order in the $21^{\text {st }}$ century, Ithaca: Cornell University Press.

Ghani, Ashraf, and Lockhart, Clare, 2008, Fixing failed states: A framework for rebuilding a fractured world, New York: Oxford University Press.

Giustozzi, Antonio, Franco, Claudio and Baczko, Adam, 2012, Shadow justice: How the Taliban run their judiciary? Integrity Watch Afghanistan.

Grace, Jo, 2005, Who owns the farm? Rural women's access to land and livestock, Kabul: Afghanistan Research and Evaluation Unit.

Huldt, Bo, and Jansson, Erland, eds., 1988, The tragedy of Afghanistan: the social, cultural and political impact of the Soviet invasion, London; New York: Croom Helm.

Kakar, Hassan M., 1995, Afghanistan: The Soviet invasion and the Afghan response, 1979-1982, Berkeley: University of California Press.

Koofi, Fawzia, 2011, Letters to my daughters, Vancouver: Douglas \& McIntyre.

Lamb, Robert D., 2012, Formal and informal governance in Afghanistan: Reflections on a Survey of the Afghan People, Occasional Paper, No.11, The Asia Foundation.

Mason, Whit, ed., 2011, The rule of law in Afghanistan: missing in inaction, Cambridge: Cambridge University Press. 
Migdal, Joel S., 1988, Strong societies and weak states: state-society relations and state capabilities in the Third World, Princeton, N.J.: Princeton University Press.

Mine Clearance Planning Agency, 2005, Survey Action Center, Landmine impact survey-Islamic Republic of Afghanistan, EU, Canada, Germany and UNDP funded.

Hynek, Nik, and Marton, Peter, eds., 2012, Statebuilding in Afghanistan: Multinational contributions to reconstruction, London: Routledge.

Ponzio, Richard, 2011, Democratic peacebuilding: aiding Afghanistan and other fragile states, Oxford: Oxford University Press.

Poullada, Leon B., 1973, Reform and rebellion in Afghanistan, 1919-1929: King Amanullah's failure to modernize a tribal society, Ithaca, N.Y.: Cornell University Press.

Saikal, Amin, 2005, Afghanistan's weak state and strong society, in Simon Chesterman, Michael Ignatieff, and Ramesh Thakur (ed.), Making states work: State failure and the crisis of governance, Tokyo; New York: United Nations University.

Tondini, Matteo, 2010, Statebuilding and justice reform: Post-conflict reconstruction in Afghanistan, London: Routledge.

Transparency International, Corruption Perceptions Index 2012, http://cpi. transparency.org/cpi2012/results/ (Accessed on 1 October 2013)

UNOCHA, News Release, 14 August 1999.

Wily, Liz Alden, 2003, Land rights in crisis: Restoring tenure security in Afghanistan, Kabul: Afghanistan Research and Evaluation Unit.

Wily, Liz Alden, 2004, Looking for peace on the pastures: Rural land relations in Afghanistan, Kabul: Afghanistan Research and Evaluation Unit.

\section{Notes}

* Yutaka Hayashi, Graduate School of Frontier Sciences, University of Tokyo, Japan Visiting Researcher, Kabul University, Afghanistan.

(Email: hayashi_yutaka@hotmail.com)

1. The total number of respondents is 70 persons in two districts. While $80 \%$ of respondents are member of society, 19\% of them are Malik or Shura members (decision makers in the community).

2. Since 1996, while three countries recognised the Islamic Emirate of Afghanistan lead by Taliban, Rabbani government represented Afghanistan in the UN.

3. Dupree 1973.

4. Most of Taliban leadership uses the title of Mullah, which indicate the rise of value of Mullah.

5. Kakar 1995, pp.141-144.

6. Huldt, Jansson eds. 1988, p.79.

7. Koofi described the fall of her own family after 1979 and described how her brother became a commander during the conflict period. Koofi 2011.

8. Willy mentioned that land tenure is not "one of the causes of turmoil" in the 1980s and 1990s, but it served as "a tipping point to conflict". Willy 2003, p. 11.

9. Willy 2004, especially, p.4.

10. Wily 2003, Deschamps and Roe 2009.

11. Deschamps and Roe, p.1.

12. Giustozzi, Franco and Baczko 2012. 
13. Paullada 1973.

14. Grace 2005, pp. 18-19.

15. Migdal 1988.

16. Saikal 2005.

17. Fukuyama 2004, 2006, Ghani and Lockhart 2008, Ponzio 2011.

18. Fukuyama 2004, Hyek \& Morton 2012.

19. Tondini 2010, Mason 2011.

20. Since 1990s, forced migration was reported by Human Rights Watch or UN. UNOCHA 1999.

21. FAO, Afghanistan - Survey of the Horticulture Sector 2003, Food and Agriculture Organization of the United Nations, Rome, 2004.

22. The numbers of Karez in Kalakan district, for instance, were 108 before the conflicts, but in 2003, only 3 Karez were remained (interviews by the author).

23. During the conflicts (against Russia and internal conflicts), those who went to Pakistan or Iran can be seen as somehow economically better because the transportation cost from their village to other counties was essential. In other words, the villagers who stayed in the countries can be seen as relatively poor (interviews by the author).

24. One respondent, Mir Hamza, explained that he requested to the then commander, Haji Daud (currently, a Member of Parliament) to join the Mujahedeen, but Haji Daud rejected his request and said that Mir Hamza should take care of his family as there were no man to take care of the house.

25. In Figure 3, electricity, agrichemicals, farming equipment are categorised as "Others".

26. For instance, on the income for farm labour during peak seasons (March-April, September-November), they can earn 300 to 400 Afghani (almost equivalent to 6 to 8 USD) per day.

27. In Pashtun dominant area, Shura is known as "Jirga". The basic idea of Shura and Jirga would be the same, meaning "Council" of people, but the detailed manner to operate Shura and Jirga would have some differences, for instance, the selection and membership of council members.

28. Interview with the Minister by the author (July, 2012).

29. Interviews by the author. Many former commanders became politicians after 2001. The Members of Parliament from Kalakan and Mir Bacha Kot districts are also former commanders in the region.

30. Lamb 2012, p.17. 